\title{
Co-administration of Rauwolfia vomitoria with Gongronema latifolium or Vernonia amygdalina on spatial learning, memory, and some bio-molecules
}

\author{
Moses B Ekong ${ }^{1}$, Aniekan I Peter ${ }^{1}$, Ubong U Ekpene ${ }^{2}$ \\ ${ }^{1}$ Department of Anatomy, University of Uyo, PMB 1017, Uyo, Nigeria, ${ }^{2}$ Department of Surgery, University of Uyo Teaching Hospital, Uyo, \\ Nigeria, This research was carried out the Neurobehavioural and biochemistry laboratories of the University of Uyo
}

\section{A B S T R A C T}

Background: Rauwolfia vomitoria is a plant with sedative properties found useful in the management of psychotic disorders, with adverse effects being reported on its use in different brain areas. Aims and Objectives: To investigate the acute effect of combination of Rauwolfia vomitoria with either Gongronema latifolium or Vernonia amygdalina on spatial learning and memory, and some bio-molecules in rats. Materials and Methods: 24 adult male Wistar rats weighing between $220 \mathrm{~g}-300 \mathrm{~g}$ were equally divided into four groups (1-4). Group 1 animals were the control treated with $0.5 \mathrm{ml}$ of Tween 20. Groups 2, 3 and 4 animals were administered respectively; $150 \mathrm{mg} / \mathrm{kg}$ of $R$. vomitoria, a combination of $150 \mathrm{mg} / \mathrm{kg}$ of $R$. vomitoria and $200 \mathrm{mg} / \mathrm{kg}$ of G. latifolium, and a combination of $150 \mathrm{mg} / \mathrm{kg}$ of $R$. vomitoria and $200 \mathrm{mg} / \mathrm{kg}$ of $V$. amygdalina for seven days. On days $4-7$ concurrent with treatment, spatial learning and memory test was carried out using the Morris water maze, and the animals were sacrificed twelve hours after the last treatment. Their sera were used for enzyme and other bio-molecules analysis. Results: There was no difference in spatial learning and memory. The activities of aspartate aminotransferase, alanine aminotransferase and alkaline phosphatase, and the serum cholesterol and triglycerides levels were also not different compared to the control group. Conclusion: The dose and duration of administration of the extract of $R$. vomitoria either alone, or in combination with $G$. latifolium or $V$. amygdalina may not affect spatial learning or memory, or alter serum biomolecules.

Key words: Rauwolfia vomitoria, Gongronema latifolium, Vernonia amygdalina, Morris water maze, Enzyme, Biomolecules, Wistar rats

\section{INTRODUCTION}

Rauwolfia vomitoria, Vernonia amygdalina and Gongronema latifolium are medicinal plants belonging to the families; Apocynaceae, Asteraceace and Asclepiadaceae, respectively. These plants individually have been reported to be beneficial to the nervous system, ${ }^{1,2}$ but the combined effect on brain areas and behaviour are limited,,$^{3-5}$ hence, the need for the present study on their acute effect on spatial learning and memory and some serum biomolecules.

R. vomitoria commonly known as swizzler stick is also called eto mmong eba ebot in Ibibio, akanta in Igbo, asofeyeji in Yoruba and wada in Hausa languages of Nigeria. ${ }^{6}$ The root bark of R. vomitoria which is mostly used traditionally constitutes $40-50 \%$ of the whole root, with alkaloids content varying from $1.7-3 \% .^{7}$ These alkaloids includes; ajmaline, ajmalicine, reserpine, serpentine, serpentinine, yohimbine among others.

Reports have shown that $R$. vomitoria possesses antipyretic and analgesic properties. ${ }^{8,9}$ Other reports showed potential anticonvulsant and antipsychotic properties. ${ }^{1,2}$ Sedative effects and decreased anxiety are among the neurological effects of this plant. ${ }^{10,11}$ Decrease of brain glutamate and increased gamma-aminobutyric acid and glutamic acid 
decarboxylase activities, ${ }^{12}$ as well as increased serum alanine aminotransferase, alkaline phosphatase and aspartate aminotransferase (AST) and albumin. ${ }^{12-14}$

G. latifolium is commonly called amaranth globe and bush buck in English. It is known as utazi in Igbo and arokeke in Yoruba languages of Nigerian. ${ }^{15}$ The plant is used for medicinal and nutritional purposes. ${ }^{16}$ The constituents of G. latifolium include; alkaloids, saponins, tannins, flavonoids and glycosides. ${ }^{16,17}$ The plant has hypoglycemic, anti-bacterial, antioxidant, anti-inflammatory, anti-ulcer, analgesic, anti-diabetic and anti-pyretic activities. ${ }^{16,18-21}$ G. latifolium is also reported to be a bittering agent, as well as having cardio-protective properties..$^{22,23}$

$V$. amygdalina commonly called bitter leaf is also called etidot in Ibibio and Efik. The plant is reported to contain alkaloids, cardiac glycosides, saponins, flavonoids, tannins and triterpenes. ${ }^{14} \mathrm{~V}$. amygdalina has a wide range of activities including hypoglycemic, ${ }^{24}$ anti-cancer, ${ }^{25,26}$ antidiabetic, ${ }^{27}$ antioxidant and hepatoprotective effects. ${ }^{28}$ Other effects include reduction in serum triglyceride and total cholesterol levels, ${ }^{24}$ as well as alanine aminotransferase activity. ${ }^{24}$

R. vomitoria is reported with wide range of adverse and beneficial neural effects. The adverse effects of this plant have necessitated its combination with other plants to counteract such adverse effects, while still maintaining its useful effects. There have been reports that this combination has improve the beneficial effect of R. vomitoria, hence, this study was to investigates acute effect of such combination on spatial learning and memory using G. latifolium or $V$. amygdalina.

\section{MATERIALS AND METHODS}

Twenty-four adult, six-month old male Wistar rats weighing between $220 \mathrm{~g}$ - $300 \mathrm{~g}$ were divided into four groups $(1-4)$. They were handled in accordance with the NIH Guidelines for the use and care of laboratory animals, with twelve hours light and darks cycles throughout the experimental period. The animals were fed with normal mice chow (Vital Feed, Nigeria) and water, and both were provided ad libitum throughout the duration of the experiment.

Freshly harvested leaves of $V$. amygdalina and G. latifolium, and roots of R. vomitoria were respectively, obtained from local farms in Ika and Esit Eket in Akwa Ibom State of Nigeria, were authenticated by a botanist. They were washed to remove impurities, and the root bark was separated from the cambium. The plant parts were air-dried, crushed to fine powder and $75-80 \%$ ethanol was used to macerate in the Soxhlet extractor. The extracts were concentrated using a rotary evaporator and the concentrates dried in a Plus 11 Gallenkamp oven at $45-50^{\circ} \mathrm{C}$. The dry extracts obtained were stored in a refrigerator at $4^{\circ} \mathrm{C}$ until used. Tween 20 was used as the vehicle to dissolve the extracts. $2 \mathrm{~g}$ of each extracts was dissolved in $30 \mathrm{~mL}$ of Tween 20 and the actual dosages were calculated.

Group 1 animals were the control treated with $0.5 \mathrm{ml}$ of Tween 20. Group 2 animals were treated with $150 \mathrm{mg} / \mathrm{kg}$ of ethanolic root bark extract of R. vomitoria. Groups 3 animals were treated with a combination of $150 \mathrm{mg} / \mathrm{kg}$ of ethanolic root bark extract of R. vomitoria and $200 \mathrm{mg} / \mathrm{kg}$ of ethanolic leaf extract of $G$. latifolium, while group 4 animals were treated with a combination of $150 \mathrm{mg} / \mathrm{kg}$ of ethanolic root bark extract R. vomitoria and $200 \mathrm{mg} / \mathrm{kg}$ of ethanolic leaf extract of $V$. amygdalina. The administration was by oral gavages in the mornings (7 am), and lasted for seven days (Table 1).

Twelve hours after the administration on days 4-7, spatial learning and memory test using the Morris water maze was carried out concurrently with the treatment. The Morris water maze was a circular pool filled with water. The maze was constructed out of a circular polypropylene pool and measured $110 \mathrm{~cm}$ in diameter and $20 \mathrm{~cm}$ in depth. A cylinder (13.75 cm x $9 \mathrm{~cm}$ diameter) was used as the escape platform in the maze. The cylinder was filled with cement to weigh it down in the pool, thus creating an invisible escape platform. The pool was filled to a depth of $14 \mathrm{~cm}$ with room-temperature tap water until the platform was submerged by $1 \mathrm{~cm}$ of water. The water was made opaque with the addition of $500 \mathrm{~g}$ of milk to ensure camouflage of the white escape platform. The pool was divided into four quadrants: Northwest, Northeast, Southwest and Southeast. Boundaries of these quadrants were marked on the edges of the pool with masking tape and labeled: North, South, East and West. The pool was located in a room measuring $5.2 \times 2.4 \mathrm{~m}$. On the walls of the room were mounted several posters to act as visual cues.

\begin{tabular}{|c|c|c|c|}
\hline $\begin{array}{l}\text { Groups } \\
n=6\end{array}$ & $\begin{array}{c}\text { Average body } \\
\text { weight (g) }\end{array}$ & $\begin{array}{l}\text { Dosage of extract } \\
(\mathrm{mg} / \mathrm{kg})\end{array}$ & $\begin{array}{c}\text { Days of } \\
\text { administration }\end{array}$ \\
\hline 1 & 226.47 & Control (Tween 20) & 7 \\
\hline 2 & 320.87 & $(150 \mathrm{mg} / \mathrm{kg}$ of $\mathrm{RV})$ & 7 \\
\hline 3 & 251.48 & $\begin{array}{l}(150 \mathrm{mg} / \mathrm{kg} \text { of } \mathrm{RV}+ \\
200 \mathrm{mg} / \mathrm{kg} \text { of } \mathrm{GL})\end{array}$ & 7 \\
\hline 4 & 294.75 & $\begin{array}{l}(150 \mathrm{mg} / \mathrm{kg} \text { of } \mathrm{RV}+ \\
200 \mathrm{mg} / \mathrm{kg} \text { of } \mathrm{VA})\end{array}$ & 7 \\
\hline
\end{tabular}

RV: Rauwolfia vomitoria, GL: Gongronema latifolium, VA: Vernonia amygdalina, Tween 20 was used as vehicle for the extracts 
There was also furniture in the room that provided visual cues. During testing, the room was dimly lit with diffuse white light (60 watt).

Testing in the Morris water maze lasted four days. The first three days were acquisition training with an invisible platform. On day four, a probe trial was conducted with no escape platform. During the test period, each rat was placed in a clean empty cage (no bedding). Paper towel was torn and placed in the bottom of the cage to allow the rats to dry more quickly. This paper towel was replaced when it became completely wet.

During acquisition training, the platform was placed in the center of the Northwest quadrant for days $1-3$. Each animal received 4 trials of 60 seconds per day. The starting positions of the animals were predetermined, which prevented any sequence of 2 trials to be repeated by the same animal during any other day. Each rat was removed from its holding cage using a small, clean $500 \mathrm{ml}$ plastic yogurt container to minimize handling stress. The animal was then placed into the water at the appropriate start position, facing the center of the pool. The rat was then permitted to explore the pool and to search for the hidden escape platform for 60 seconds. When the animal located the platform, the timer was stopped and the animal was removed using the plastic container and placed in the holding cage. If the animal did not find the platform during the allotted time, the animal was guided onto the platform using the plastic container. Once on the platform, the rats were permitted to visually explore their surroundings for 20 seconds at which point, the researcher picked up the rat in the plastic container and returned the mouse to the appropriate holding cage. Each animal completed 4 trials per day over 3 days, for 12 trials of acquisition training. During acquisition training the swim latency (time to find and mount the escape platform) was measured (Whishaw, 1985).

A probe trial was conducted on day 4. At this time, there was no escape platform in the maze at all. Each animal completed one trial of 60 seconds. Each rat was placed in the maze from one of the four possible start positions and allowed to explore the pool. During the probe trial; the duration of time spent in each quadrant (Northeast, Southeast, Northwest, Southwest). Memory represents the time spent in the target quadrant during the probe trial.

Immediately after the behavioral test, the animals were anaesthetized using chloroform fumes, and were sacrificed. Their thoraco-abdominal walls were excised and blood was aspirated by means of syringe and needle from the left ventricle for the determination of serum levels of cholesterol and triglyceride, as well as the activities of aspartate aminotransferase (AST), alanine aminotransferase (ALT) and alkaline phosphatase (ALP).

\section{Statistical analysis}

One way analysis of variance (ANOVA) was used to compare the means for the serum enzyme activities and lipid levels, while repeated measures ANOVA was used to analyze the Morris water maze activities, thereafter the post-hoc test using Student-Newman-Keuls multiple comparisons test was carried out to find the level of significance at $\mathrm{p}<0.05$. All the results were expressed as mean \pm standard error of mean.

\section{RESULTS}

At the end of the experiment body weights were reduced in all the groups, though the groups administered R. vomitoria alone, and in combination with either $V$. amygdalina or G. latifolium were significantly $(\mathrm{p}<0.05)$ lower compared to the control. The group administered $R$. vomitoria alone had significant $(\mathrm{p}<0.05)$ body weight loss compared to its combination groups (Table 2)

The Morris water maze test showed no difference in the groups administered the plant extracts (R. vomitoria, $V$. amygdalina and $G$. latifolium) compared to the control in the acquisition trial (spatial learning) and in the probe trial (memory). There was also no difference between the plant extract groups (Tables 3 and 4).

There was no difference in the activities of aspartate aminotransferase, alanine aminotransferase and alkaline phosphatase compared with the control group. The

\begin{tabular}{|c|c|c|c|c|}
\hline $\begin{array}{l}\text { Groups } \\
(n=6)\end{array}$ & $\begin{array}{l}\text { Initial body weight }(\mathrm{g}) \\
\qquad \begin{array}{c}\mathrm{P} \\
\mathrm{F}=50.0001\end{array}\end{array}$ & $\begin{array}{l}\text { Final body weight (g) } \\
\qquad \begin{array}{c}P<0.0001 \\
F=27.631\end{array}\end{array}$ & $\begin{array}{l}\text { Loss in } \\
\text { weight (g) }\end{array}$ & $\begin{array}{c}\text { Loss in } \\
\text { weight (\%) }\end{array}$ \\
\hline 1. Control (Tween 20) & $225.80 \pm 2.41$ & $210.50 \pm 2.10$ & 15.3 & 6.78 \\
\hline 2. (150 mg/kg of RV) & $320.87 \pm 4.13^{*, \mathrm{c}, \mathrm{d}}$ & $267.88 \pm 6.84^{*, c, d}$ & $55.99^{*}$ & 17.45 \\
\hline 3. (150 mg/kg of RV+200 mg/kg of GL) & $251.48 \pm 4.32^{*, d}$ & $225.18 \pm 8.09^{d}$ & $26.3^{*, b}$ & 10.46 \\
\hline 4. $(150 \mathrm{mg} / \mathrm{kg}$ of $\mathrm{RV}+200 \mathrm{mg} / \mathrm{kg}$ of $\mathrm{VA})$ & $294.75 \pm 2.33^{*}$ & $264.43 \pm 1.22^{*}$ & $30.32^{*, b}$ & 10.29 \\
\hline
\end{tabular}

Data are presented as mean \pm standard error of mean, $*$ Significantly different from group 1 at $p<0.05$, bSignificantly different from group 2 at $p<0.05$, NS: Not significantly different from group 1 at $p<0.05$, 'Significantly different from group 3 at $p<0.05{ }^{\mathrm{d} S}$ Significantly different from group 4 at $p<0.05^{\prime}$ has been added 
serum cholesterol and triglycerides levels also showed no difference compared with the control group (Table 5).

\section{DISCUSSION}

R. vomitoria, G. latifolium and V. amygdalina are useful medicinal herbs that possess several important functions including; antioxidant and hypoglycemic properties. ${ }^{12,14}$ R. vomitoria use has been associated with some adverse effects, thus, the present study investigated the potentials of co-administration of extract of $R$. vomitoria with either $G$. latifolium or $V$. amygdalina on spatial learning, memory and some bio-molecules.

\begin{tabular}{|c|c|c|c|}
\hline $\begin{array}{l}\text { Groups } \\
(n=6)\end{array}$ & $\begin{array}{c}\text { Day } 1 \\
P=0.8274 \\
F=0.2970\end{array}$ & $\begin{array}{c}\text { Day } 2 \\
P=0.4457 \\
F=0.9001\end{array}$ & $\begin{array}{c}\text { Day } 3 \\
P=0.8668 \\
F=0.2419\end{array}$ \\
\hline 1. Control (Tween 20) & $34.73 \pm 5.07$ & $23.57 \pm 4.37$ & $14.83 \pm 3.10$ \\
\hline 2. $(150 \mathrm{mg} / \mathrm{kg}$ of RV) & $33.50 \pm 4.41^{\mathrm{NS}}$ & $25.50 \pm 4.99^{N S}$ & $11.53 \pm 2.87^{\mathrm{NS}}$ \\
\hline $\begin{array}{l}\text { 3. }(150 \mathrm{mg} / \mathrm{kg} \text { of } R V+ \\
200 \mathrm{mg} / \mathrm{kg} \text { of } \mathrm{GL})\end{array}$ & $31.33 \pm 5.23^{\mathrm{NS}}$ & $18.39 \pm 3.93^{\mathrm{NS}}$ & $13.90 \pm 4.46^{\mathrm{NS}}$ \\
\hline $\begin{array}{l}\text { 4. (150 mg/kg of RV+ } \\
200 \mathrm{mg} / \mathrm{kg} \text { of VA) }\end{array}$ & $33.45 \pm 4.51^{\mathrm{NS}}$ & $16.53 \pm 3.20^{\mathrm{NS}}$ & $11.75 \pm 2.77^{\mathrm{NS}}$ \\
\hline
\end{tabular}

Data are presented as mean \pm standard error of mean, NS: Not significantly different from group 1 at $\mathrm{p}<0.05$, RV: Rauwolfia vomitoria, GL: Gongronema latifolium, VA: Vernonia amygdalina

\begin{tabular}{|c|c|c|}
\hline \multirow{2}{*}{$\begin{array}{l}\text { Groups } \\
(n=6)\end{array}$} & \multicolumn{2}{|c|}{ Probe trial } \\
\hline & $\begin{array}{c}\text { Target quadrant } \\
P=0.2504 \\
F=1.492\end{array}$ & $\begin{array}{c}\text { Outer quadrant } \\
\qquad \begin{array}{c}P=0.250 \\
F=1.49\end{array}\end{array}$ \\
\hline 1. Control (tween 20) & $20.18 \pm 3.72$ & $39.82 \pm 3.72$ \\
\hline 2. (150 mg/kg of RV) & $12.01 \pm 2.97^{\mathrm{NS}}$ & $47.99 \pm 2.97$ NS \\
\hline $\begin{array}{l}\text { 3. }(150 \mathrm{mg} / \mathrm{kg} \text { of } \mathrm{RV}+ \\
200 \mathrm{mg} / \mathrm{kg} \text { of } \mathrm{GL})\end{array}$ & $18.94 \pm 2.91^{\mathrm{NS}}$ & $41.06 \pm 2.91^{\mathrm{NS}}$ \\
\hline $\begin{array}{l}\text { 4. }(150 \mathrm{mg} / \mathrm{kg} \text { of } R V+ \\
200 \mathrm{mg} / \mathrm{kg} \text { of VA) }\end{array}$ & $18.13 \pm 1.52^{\mathrm{NS}}$ & $41.87 \pm 1.52^{\mathrm{NS}}$ \\
\hline
\end{tabular}

Data are presented as mean \pm standard error of mean, NS: Not significantly different from group 1 at $\mathrm{p}<0.05$, RV: Rauwolfia vomitoria, GL: Gongronema latifolium, VA: Vernonia amygdalina
At the end of the experiment, the animal's body weights were reduced in all the groups, likely due to handling stress, which is often associated with weight loss. ${ }^{29}$ The groups administered R. vomitoria alone, and in combination with either $G$. latifolium or $V$. amygdalina had significantly $(p<0.05)$ reduced body weights compared to the control group. This loss in body weight may be due to the activity of the constituents of R. vomitoria, as R. vomitoria has been reported to cause body weight loss in rats and mice. ${ }^{4,10,30}$ However, the group administered only $\mathrm{R}$. vomitoria had significant $(p<0.05)$ body weight loss compared to its combination groups, an indication that the interaction of these other herbs may have modulated the unilateral action of the R. vomitoria. This report is similar to a report on mice administered the combination of $R$. vomitoria and G. Latifolium..$^{30}$ It is deduced therefore that R. vomitoria extract alone may be useful in body weight gain control, and may also result in an uncontrolled body weight loss, which the combination tends to assuage.

Spatial learning (acquisition trial) and memory (probe trial) activities in the Morris water maze of the test groups were not different from the control group. This indicates that the treatment regimes may be insufficient to cause change in the animals' ability to learn and/or remember. The Morris water maze has been used extensively to study the effects of brain injury or drugs on spatial learning. ${ }^{31-33}$ This result suggests that the brain areas involved in this function may not be affected by the treatments.

There was no difference in the activities of aspartate aminotransferase (AST), alanine aminotransferase (ALT) and alkaline phosphatase (ALP) compared with the control group. AST, ALT and ALP are enzymes in the liver and brain that serve as markers for the damage of these tissues. ${ }^{34}$ This result indicates that the treatment regimes were insufficient to alter the cellular integrity of the liver and the brain, among other organs of the body. This result is at variance with previous studies, which reported that R. vomitoria increases serum alanine aminotransferase and alkaline phosphatase activities. ${ }^{12,14}$ The difference may be due to the administered doses, as $542 \mathrm{mg} / \mathrm{kg}, 200 \mathrm{mg} / \mathrm{kg}$,

\begin{tabular}{|c|c|c|c|c|c|}
\hline $\begin{array}{l}\text { Groups } \\
(n=6)\end{array}$ & $\begin{array}{c}\text { AST (nkat/L) } \\
P=0.160 \\
F=1.95\end{array}$ & $\begin{array}{c}\text { ALT (nkat/L) } \\
P=0.672 \\
F=0.52\end{array}$ & $\begin{array}{c}\text { ALP (nkat/L) } \\
P=0.917 \\
F=0.17\end{array}$ & $\begin{array}{c}\text { Cholesterol }(\mathrm{mg} / \mathrm{dl}) \\
\mathrm{P}=0.494 \\
\mathrm{~F}=0.83\end{array}$ & $\begin{array}{c}\text { TG }(\mathrm{mg} / \mathrm{dl}) \\
P=0.542 \\
F=0.74\end{array}$ \\
\hline 1. Control (tween 20) & $1927.30 \pm 204.92$ & $648.40 \pm 33.17$ & $4277.66 \pm 436.03$ & $92.30 \pm 6.55$ & $87.00 \pm 13.97$ \\
\hline 2. $(150 \mathrm{mg} / \mathrm{kg}$ of RV) & $1554.68 \pm 307.79^{\mathrm{NS}}$ & $847.34 \pm 237.12^{\mathrm{NS}}$ & $4639.19 \pm 852.97^{\mathrm{NS}}$ & $79.72 \pm 5.92^{\mathrm{NS}}$ & $85.87 \pm 9.14^{\mathrm{NS}}$ \\
\hline $\begin{array}{l}\text { 3. (150 mg/kg of RV+ } \\
200 \mathrm{mg} / \mathrm{kg} \text { of } \mathrm{GL})\end{array}$ & $1833.19 \pm 164.20^{\mathrm{NS}}$ & $837.02 \pm 132.00^{\mathrm{NS}}$ & $4498.83 \pm 223.43^{\mathrm{NS}}$ & $88.58 \pm 5.73^{\mathrm{NS}}$ & $105.47 \pm 8.57^{\mathrm{NS}}$ \\
\hline $\begin{array}{l}4(150 \mathrm{mg} / \mathrm{kg} \text { of } \mathrm{RV}+ \\
200 \mathrm{mg} / \mathrm{kg} \text { of VA) }\end{array}$ & $1375.39 \pm 94.64^{\mathrm{NS}}$ & $761.37 \pm 116.01^{\mathrm{NS}}$ & $4746.74 \pm 539.20^{\mathrm{NS}}$ & $84.01 \pm 2.70^{\mathrm{NS}}$ & $100.75 \pm 9.74^{\text {NS }}$ \\
\hline
\end{tabular}

Data are presented as mean \pm standard error of mean, NS: Not significantly different from group 1 at p<0.05, RV: Rauwolfia vomitoria, GL: Gongronema latifolium, VA: Vernonia amygdalina, AST: Aspartate aminotransferase, ALT: Alanine aminotransferase, ALP: Alkaline phosphatase, TG: Triglyceride 
and $4000 \mathrm{mg} / \mathrm{kg}$ body weight extracts of R. vomitoria were given.

Serum cholesterol and triglycerides levels predict cardiovascular, as well as other organs state. ${ }^{35}$ In the present study there was no difference in cholesterol and triglycerides levels in the R. vomitoria alone or in its combination compared to the control. This result indicates that the treatment regime may not have caused any injury to the cardiovascular or other organs. This result supports other parameters already reported.

R. vomitoria is reported to sedate animals, ${ }^{3,10}$ and this could be fatal due to the animals' inability to fend for themselves. A combination treatment with G. latifolium is shown to modulate the sedative effect and to ameliorate cytological alteration, $, 3,5$ a potential that can be exploited for the safe use of the herbs. Though the present study did not result in adverse reaction beyond body weight loss, spatial learning, memory and serum biomolecules level which are vital in life may be affected if the dosage or duration of use is altered, hence the need to control their intake.

In conclusion, at the dose and duration of administration, the extract of $R$. vomitoria either alone or in combination with $G$. latifolium or $V$. amygdalina may not affect spatial learning or memory or alter serum biomolecules.

\section{REFERENCES}

1. Amole OO, Yemitan OK and Oshikoya KA. Anticonvulsant activity of Rauvolfia Vomitoria (Afzel). Afr J Pharm Pharmacol 2009; 3(6): 319-322.

2. Bisong SA, Brown R and Osim EE. Comparative extrapyramidal effects of Rauwolfia vomitoria, chlorpromazine and reserpine in mice. J Nat Med 2013; 67(1): 107-112.

3. Ekong MB, Peter Al, Davies K, Bassey El, Aquaisua AN, Akpanabiatu MI, et al. J Neurochem 2013; 125(S1): 369.

4. Ekong MB, Peter MD, Peter AI, Eluwa MA, Umoh IU, Igiri AO, et al. Cerebellar neurohistology and behavioural effects of gongronema latifolium and rauwolfia vomitoria in mice. Met Brain Dis 2014; 29: 521-527.

5. Ekong MB, Peter Al, Ekpene UU, Bassey El, Eluwa MA, Akpanabiatu $\mathrm{Ml}$, et al. G. latifolium modulates R. vomitoriainduced behaviour and histomorphology of the cerebral cortex. Intern J Morphol 2015; 33(1): 77-84.

6. Ehiagbonare EJ. Regeneration of Rauwolfia vomitoria. Afr J Biotech 2004; 6(8): 979-981.

7. Sharma R. Agro-techniques of medicinal plants. New Delhi: Daya Publishing House; 2004.

8. Amole $\mathrm{OO}$ and Onabanjo AO. Antipyretic effect of the extract of Rauvolfia vomitoria (Afzel) in rabbits. Nig J Nat Prod Med 1999; 3: 77-78.

9. Amole OO, Onabanjo AO and Odofin AA. The analgesic effect of Rauvolfia vomitoria (Afzel). Biomed.I Res 2006; 17: 125-127.

10. Eluwa MA, Idumesaro NB, Ekong MB, Akpantah $A O$ and Ekanem TB. Effect of aqueous extract of Rauwolfia vomitoria root bark on the cytoarchitecture of the cerebellum and neurobehaviour of adult male Wistar rats. Internet J Alternative Med [Internet].2009[cited2014 June];6(2). Available from http:// ispub.com/IJAM/6/2/3081.

11. Bisong SA, Brown $R$ and Osim EE. Comparative effects of Rauwolfia vomitoria and chlorpromazine on locomotor behaviour and anxiety in mice. J Ethnopharmacol 2010; 132(1): 334-339.

12. Ebuehi DA and Aleshinloye OO. Extracts of Cnestis ferruginea and Rawolfia vomitoria affect blood chemistry and GABAergic neurotransmission in ketamine-induced psychotic rats. Nig Q J Hosp Med 2010; 20(4): 171-176.

13. Akpanabiatu MI, Uboh FE, Ekanem TB, Umoh IB, Eyong EU and Ukafia SO. The effect of interaction of Rauwolfia vomitoria root bark extract with vitamin E on rats' liver enzymes. Turk J Biol 2009; 33: 189-194.

14. Eteng MU, Ibekwe HA, Abolaji AO, Okoi Al, Onwuka FC and Osuchukwu NC. Effect of Rauwolfia vomitoria Afzel (Apocynaceae) extract on serum amino transferase and alkaline phosphatase activities and selected indices of liver and kidney functions. Afr J Biotech 2009; 8(18): 4604-4607.

15. Rahaman O. Uses of Rauwolfia vomitoria afzel (asofeyeje) in African traditional medicine [Internet]. 2010[cited2013 July]. Available from: http://searchwarp.com/swa601674-Uses-OfRauwolfia-Vomitoria-Afzel-Asofeyeje-In-African-TraditionalMedicine.htm.

16. Eleyinmi AF, Adebowale YA, Oluwalana IB, Ajisafe OJ and Akintomide TF. Effect of dietary inclusion of Garcinia kola, Gongronema latifolium and Vernonia amygdalina on the nutritional quality of a complementary diet. Res J Biol Sci 2006; 1(1-4): 43-49.

17. Nwinyi OC, Nwodo SC and Ajani OO. Evaluation of antibacterial activity of Pisidum guajava and Gongronema latifolium. J Med Plants Res 2008; 2(8): 189-192.

18. Morebise O, Fafunso MA, Makinde JM, Olajide OA and Awe EO. Antiinflamatory property of the leaves of Gongronema latifolium. Phytother Res 2002; 16(S1): 75-77.

19. Ogundipe OO, Moody JO, Akinyemi TO and Raman A. Hypoglycemic potentials of methanolic extracts of selected plant foods in alloxanized mice. Plant Foods Hum Nutr 2003; 58(3): 1-7.

20. Ugochukwu NH, Babady NE, Cobourne M and Gasset SR. The effect of Gongronema latifolium extracts on serum lipid profile and oxidative stress in hepatocytes of diabetic rats. J Biosci 2003; 28: 1-5.

21. Akuodor GC, Idris-Usman MS, Mbah CC, Megwas UA, Akpan JL, Ugwu TC, et al. Studies on anti-ulcer, analgesic and antipyretic properties of the ethanolic leaf extract of Gongronema latifolium in rodents. Afr J Biotech 2010; 9(15): 2316-2321.

22. Adenuga $\mathrm{W}$, Olaleye $\mathrm{ON}$ and Adepoju PA. Utilization of bitter vegetable leaves (Gongronema latifolium, Vernonia amygdalina) and Garcinia kola extracts as substitutes for hops in sorghum beer production. Afr J Biotech 2010; 9(51): 8819-8823.

23. Glew RS, VanderJagt DJ, Huang YS, Chuang LT, Bosse R and Glew RH. Nutritional analysis of the edible pit of Sclerocarya birrea in the Republic of Niger (daniya, Hausa). J Food Comp Anal 2004; 17(1): 99-111.

24. Eteng MU, Bassey BJ, Atangwho IJ, Egbung GE, Eyong EU, Ebong PE, etal. lochemical indices of macrovascular complication in diabetic rat model: Compared effects of Vernonia amygdalina, Catharantus roseus and chlorpropamide. Asian $\mathrm{J}$ of Biochem 2008; 3(4): 228-234.

25. Gresham LJ, Ross J and Izevbigie EB. Vernonia amygdalina: Anticancer activity, authentication, and adulteration detection. Int. J. Environ. Res. Public Health 2008; 5(5): 342-348.

26. Oyugi DA, Luo X, Lee KS, Hill B and Izevbigie EB. Activity Markers of the Anti-Breast Carcinoma Cell Growth Fractions of Vernonia 
amygdalina Extracts. Exp Biol Med 2009; 234: 410-417.

27. Ebong PE, Atangwho JI, Eyong EU and Egbung GE. Am J Biochem Biotech 2008; 4 (3): 239-244.

28. Iwalokun BA, Efedede BU, Alabi-Sofunde JA, Oduala T, Magbagbeola OA and Akinwande Al. Hepatoprotective and Antioxidant Activities of Vernonia amygdalina on Acetaminophen-Induced Hepatic Damage in Mice. J Med Food 2006; 9(4): 524-530.

29. Voisinet BD, Grandin T, Tatum JD, O'Connor SF and Struthers $\mathrm{JJ}$. Feedlot cattle with calm temperaments have higher average daily gains than cattle with excitable temperaments. J Anim Sci 1997; 75: 892-896.

30. Ekong MB, Ekpene UU, Thompson FE, Peter Al, Udoh NB and Ekandem GJ. Effects of co-treatment of rauwolfia vomitoria and gongronema latifolium on neurobehaviour and the neurohistology of the cerebral cortex in mice. Internet $\mathrm{J}$ Med Update 2015; 10(1): 3-10.

31. Von Lubitz D, Paul I, Bartus R and Jacobson K. Effects of chronic administration of adenosine A1 receptor agonist and antagonist on spatial learning and memory. Eur J Pharmacol 1993; 249: 271-280.

32. Fordyce D, Clark V, Paylor R and Wehner J. Enhancement of hippocampally-mediated learning and protein kinase $C$ activity by oxiracetam in learning-impaired DBA/2 mice. Brain Res 1995; 672: 170-176.

33. Fox $G$, LeVasseur $R$ and Faden A. Behavioral responses of C57BL/6, FVB/N, and 129/SvEMS Mouse strains to traumatic brain injury: Implications for gene targeting approaches to neurotrauma. J Neurotrauma 1998; 16: 377-389.

34. Gumma K, Kulkarni GP and Padmanabha TS. Effect of phyneto in sodium on liver function tests. Intern J Pharma Bio Sci 2014; 5(1): 249-252.

35. Hokanson JE and Austin MA. Plasma triglyceride level is a risk factor for cardiovascular disease independent of high-density lipoprotein cholesterol level: A meta-analysis of populationbased prospective studies. J Cardiovasc Risk 1999; 3: 213-219.

\footnotetext{
Authors Contribution:

MBE - Initiated and carried out the research, and wrote the manuscript; AIP - Gathered data and participated in the research activity and revised the manuscript; UUE - Gathered data and participated in the research activity and revised the manuscript.

Source of Support: Nil, Conflict of Interest: None declared.
} 